\title{
The Association Among Working Capital Managementand Profit Ability of Telecommunication Firms
}

\author{
Avani Raval and Ashvin Dave \\ ${ }^{1}$ Department of Business Administration and Commerce, School of Liberal Studies, \\ Pandit Deendayal Energy University, Raisan, Gandhinagar, Gujarat, India. \\ Corresponding author email: avaniraval04@gmail.com
}

\section{ABSTRACT}

This research study aims to examine working capital management practice carried out by Tele Communication companies listed on BSE/NSE. The study tries to undertake the data evaluation of selected variables for the tenure of ten years i.e. 2010-2019.The aim of this study is get to know association between dependent and independent component. Dependent Variable is a profit after tax to sales ratio and Independent Variables is a Sales Growth Rate, Cash, Bank \&Marketable Security, Fixed Assets Turnover Ratio, and Long Term Debt Equity Ratio. Matrix of Co-efficient of Correlations, Descriptive and Regression has been used for analysis. The result shows that only two variables has moderately significant and positive relation among Cash, Bank EtMarketable Security, Fixed Assets Turnover Ratio and profit after tax to sale ratio and rest of two variable viz. Sales Growth Rate and Long Term Debt Equity Ratio has insignificantly positive relation with profit after tax to sale ratio.

\section{KEY WORDS: SALES GROWTH RATE, CASH, BANK \& MARKETABLE SECURITY, REGRESSION.}

\section{INTRODUCTION}

When a corporation invests in current assets, it has been think about as working capital in the custom sensibility. All industrial corporations' is effect by working capital management resolution as it has an effect on the liquidity of the company. Working capital management is preciselyimportant part for management day to day costs. . Working capital management is exercise that bears current ratio.Working capital management is atool of business. Deprived of working capital management is a necessity for everyprosperousoccupational.Alike to long term assetresolutions there has to be a proper evaluation of the merits and demerits with respect to everyelement of current assets while taking working capital results. Cash flow plays a dynamic role in working capital resolutions and long term investment resolution.

Biosc Biotech Res Comm P-ISSN: 0974-6455 E-ISSN: 2321-4007

\section{crossef}

Identifiers and Pagination

Year: 2021 Vol: 14 No (5) Special Issue

Pages: 194-197

This is an open access article under Creative

Commons License Attribn 4.0 Intl (CC-BY). DOI: $h t t p: / / d x$.doi.org/10.21786/bbrc/14.5/35
The important part of variance with respect to long term resolutions and working capital results is the time line of managementpractice. Working capital conclusions in the usualsituation has an effect on the cash flows of the company for a short time i.e. maximum one year.

Literature Review: Shikha Bhatia, Aman Srivastava (2016) in their study 179 firm a sample of 179 firms listed on SAP for the period of 13 years i.e. 2002 to 2014. They had taken gross operating profit and Tobin's $\mathrm{Q}$ as dependent variable and cash conversion cycle accounts receivable days, inventory days and accounts payable days as independent variable and size, sales growth, leverage, fixed financial assets, variability of net operating income and growth in GDP as control variables. Descriptive, regression, correlation analysis, panel data analysishave been used for this study. Result indicates that independent and control have significantly influence on profitability.

Dr. Benjamin Owuor Ombok, Judith Auma Omanga and Grace Ivy A. Odongo(2017) analysed four sugar companies over a period of ten years i.e. 2005 to 2014. They had taken return on assets as dependent variable and Average collection period (ACP); Inventory turnoverin days (ITO);
Article Information

Received: $28^{\text {th }}$ Jan 2021 ccepted after revision: $30^{\text {th }}$ Mar 2021 
Average payment period (APP) and Cash conversion cycle as independent variables.Regression analysis and penal data methodology have been used in this study. It was notice that all independent componentshad a more impact on profitability.

Dr. Johnson Abiodun Oladimeji \& Dr. Olufemi Aladejebi (2020) examine30 SMEs for the period of 5 years i.e. 2014 to 2018. They had taken return on assets as dependent variable and Account Collection Period, Inventory Conversion Period, Average Payment Period, Cash Conversion Cycle, Debt Ratio, Current Ratio and Quick Ratio as independent variables. They were used descriptive statistics, correlation and regression analysis. It was notice that there is insignificant association among independent variable and profitability. Point out that there is negative relationship with Account Collection Period, Average Payment Period and profitability.

Zbigniew Gołas (2020) examined 76 police milk industry over a time period of ten years with the span of 2008 to 2017. Researcher had taken return on assets as dependent variable and Days Sales of Inventory, Days Sales Outstanding, Days Payable Outstanding and the Cash Conversion Cycle as independent variables. Descriptive, matrix correlation and regression analysis have been used in this study.Results indicate that there is negative association among profitability and working capital cycle. Phadindra Kumar Poudel and Pujan Maharjan (2020) examine the performance of 10 non -financial companies over a period of five years i.e. 2071-72 to 2075-76. The variable measure return on assets as dependent variable and days sales outstanding, days inventory outstanding, cash conversion cycle, current ratio as independent variable. Descriptive, correlation, regression analysis have been used in this study. It was notice that there is significantly positive relationship among current ratio and profitability. Point out that there is significantly negative association among Days' sales outstanding and financial performance of the company.

Dr. Namita Yash (2021) examined the dabur India ltd. company over a time period of 15 years i.e. 2005-06 to 2019-20. She considered current assets, current liability, net working capital, inventory turnover ratio, receivable turnover ratio, cash turnover ratio, working capital turnover ratio, gross working capital, total assets, working capital leverage return on net worth ratio and liquidity ratio as variable. She used ratio analysis, rank test, averages, standard deviation, co-efficient variations, and correlation coefficient. Result shows that there is negative relationship with profitability and liquidity.

\section{RESEARCH METHODOLOGY}

This study has measured only fourteen telecom companies over a time period of ten years i.e. 2009 to 2019. The evidence was acquired from Capitaline database. The aim of this study is get to know association between dependent and independent component. Dependent Variable is a profit after tax to sales ratio and
Independent Variables is a Sales Growth Rate, Cash, Bank \&tMarketable Security, Fixed Assets Turnover Ratio, and Long Term Debt Equity Ratio.Matrix of Co-efficients of Correlations, descriptive and regression has been used for analysis.

Objectives: The objective of this study is to know and assess the extent of impact and the relationship among dependent and independent variable of the business enterprise in the telecommunication sector.

\section{Hypothesis}

H0: SGR has positive association with PATSR.

H1: SGR has no positive association with PATSR.

HO: CB\&MS has positive association with PATSR.

H1: CBEMS has positive association with PATSR.

Ho: FATR has positive association with PATSR.

H1: FATR has positive association with PATSR.

HO: LTDER has positive association with PATSR.

H1: LTDER has positive association with PATSR.

\section{Analysis And Interpretation}

1. Table -1 indicate that the matrix of co-efficient of correlations between independent variables i.e. LTDR, SGR, CBEMS, FATR have been considered by karl-person coefficient of correlation. It is precisely displays that all component of co-efficient of correlations' value has not more than +0.1 and VIF data not close by 10 . Thus the difficultly of multi co linearity does not occur between the independent component.

2. Table - 2 obtainable the element of descriptive statistics. The outcomes presented this studied will be more suitable to the organisations whose data sets resemble the descriptive method indicate in Table - 2 .

3. Table - 3 obtain the regression coefficient. It is specifying that direction; standardized Beta, significance level, values and VIF are remark in Table - 3. Table - 3 displays that Sales Growth Rate, Cash, Bank EtMarketable Security, Fixed Assets Turnover Ratio, and Long Term Debt Equity Ratio as independent variables has association with profit after tax to sales ratio. The $\beta$ of debt equity ratio as presented in Table -3 , stands at +0.108 viz. indicate that Sales Growth Rate has positive relationship with profit after tax to sales ratio.The value of significance level is 0.207 . It is notice that the significance coefficient beta $(\beta)$ is statistically insignificance. Therefore null hypothesis (SGR) is accepted and $\mathrm{H} 1$ be rejected.

4. Table - 3 measured the cost of Cash, Bank EtMarketable Security i.e. 0.114 it is revel that $\beta$ has positive relationship with profit after tax to sales ratio. The value of significance level is 0.180 
it means $\beta$ is statistically moderately significant. Thus null hypothesis (ICR) be accepted and H1 be rejected.

5. The $\beta$ of fixed assets turnover ratio as presented in Table -3 , stands at +0.139 viz. point out that fixed assets turnover ratio has positive relationship with profit after tax to sales ratio. The value of significance level is 0.106 . It means that the significance coefficient beta $(\beta)$ is statistically moderate. Therefore null hypothesis (CR) be accepted and $\mathrm{H} 1$ be rejected.

6. Table -3 considered the long term debt equity ratio viz. +0.038 it is revel that $\beta$ has positive association with profit after tax to sales ratio. The value of significance level is 0.649 it means $\beta$ is statistically not significant. Thus null hypothesis be accepted and alternate hypothesis be rejected.

Table 1. Matrix of Co-efficients of Correlations

\begin{tabular}{|l|c|c|c|c|}
\hline & SGR & CB\&tMS & FATR & LTDR \\
\hline SGR & 1.000 & -0.023 & 0.177 & 0.018 \\
\hline CBCtMS & -0.023 & 1.000 & -0.079 & -0.062 \\
\hline FATR & 0.177 & -0.079 & 1.000 & 0.026 \\
\hline LTDR & 0.018 & -0.062 & 0.026 & 1.000 \\
\hline
\end{tabular}

Table 2. Descriptive Statistics

\begin{tabular}{|l|c|c|c|c|c|}
\hline Variables $\rightarrow$ & PTSAR & SGR & CB\&MS & FATR & LTDER \\
\hline Mean & -0.09078 & 10.3976 & 0.13627 & 0.5944 & 0.9953 \\
\hline Std. Deviation & 0.73826 & 40.5573 & 0.35404 & 0.6758 & 5.32254 \\
\hline
\end{tabular}

Table 3. Regression Co-efficients

\begin{tabular}{|c|c|c|c|c|c|}
\hline & \multicolumn{2}{|c|}{$\begin{array}{l}\text { Regression } \\
\text { Co-efficients }\end{array}$} & \multirow[t]{2}{*}{ t } & \multirow{2}{*}{$\begin{array}{l}\text { Significance } \\
\text { Level }\end{array}$} & \multirow[t]{2}{*}{ VIF } \\
\hline & Direction & Value & & & \\
\hline \multicolumn{6}{|l|}{ Constant } \\
\hline SGR & + & 0.108 & 1.267 & 0.207 & 1.033 \\
\hline CB\&MS & + & 0.114 & 1.348 & 0.180 & 1.010 \\
\hline FATR & + & 0.139 & 1.629 & 0.106 & 1.039 \\
\hline LTDER & + & 0.038 & 0.456 & 0.649 & 1.004 \\
\hline \multicolumn{6}{|c|}{ Dependent Variable : PATSR $\quad \mathbf{R}^{2}=0.020$} \\
\hline Independen & lables:SG & $\mathrm{R}, \mathrm{CB}$ & MS, F & $\Gamma \mathrm{R}, \mathrm{LTDER}$ & $N=140$ \\
\hline
\end{tabular}

\section{Findings}

1. It is find that there is insignificantly positive association among Sales Growth Rate and profit after tax to sales ratio and the significance coefficient beta $(\beta)$ is statistically not relevant.

2. Further find that Cash, Bank \&Marketable Security has favourably association with profit after tax to sales ratio and significant co-efficient beta is statistically moderately significant.

3. The fixed assets turnover ratio has positive association with profitability and significance coefficient beta is statistically moderately significance.

4. It is notice that long term debt equity ratio has positive association with profit after tax to sale ratio but statistically significant co-efficient beta is not relevant.

\section{CONCLUSION}

The research disclosed relationship between Sales Growth Rate, Cash, Bank \& Marketable Security, Fixed Assets Turnover Ratio, and Long Term Debt Equity Ratio and profit after tax to sale ratio that there is positive association between Sales Growth Rate, Cash, Bank \&tMarketable Security, Fixed Assets Turnover Ratio, and Long Term Debt Equity Ratio and profit after tax to sale ratio. The result shows that only two variables has moderately significant and positive relation among Cash, 
Bank EtMarketable Security, Fixed Assets Turnover Ratio and profit after tax to sale ratioand rest of two variable viz. Sales Growth Rate and Long Term Debt Equity Ratio has insignificantly positive relation with profit after tax to sale ratio.

\section{REFERENCES}

Aladejebi, D. J. (2020). The Impact of Working Capital Management on Profitability: Evidence from Selected Small Businesses in Nigeria. Journal of Small Business and Entrepreneurship Development, 8(1), 27-40.

Dr. Benjamin Owuor Ombok, J. A. (2017). WORKING CAPITAL MANAGEMENT PRACTICES ON FINANCIAL PERFORMANCE OF PUBLIC OWNED SUGAR FIRMS IN WESTERN REGION, KENYA. International Journal of Current Research, 9(8), 56000-56005.
Gołas, Z. (2020). Impact of working capital management on business profitability: Evidence from the Polish dairy industry. Agriculture Economics - Czech, 66(6), 278-285.

Maharjan, P. K. (2020). Effect of working capital management on profitability: A case of Nepalese manufacturing firms. The International Research Journal of Management Science, 5(1), 130-147.

Shikha Bhatia, A. S. (2016). Working Capital Management and Firm Performance in Emerging Economies: Evidence from India. Management and Labour Studies, 41(2), 7187.

Yash, D. N. (2021). Management of Working Capital in Nature based Industry (A Case Study of Dabur India Limited). Global Journals, 21(2), 57-65. 